University of Nebraska - Lincoln

DigitalCommons@University of Nebraska - Lincoln

Publications, Agencies and Staff of the U.S.

Department of Commerce

U.S. Department of Commerce

$1-2008$

Determining spatial and temporal scales for management: lessons from whaling

\author{
P J. Clapham \\ Phillip.Clapham@noaa.gov \\ Alex Aguilar \\ University of Barcelona \\ Leila Hatch \\ Gerry E. Studds Stellwagen Bank National Marine Sanctuary, National Ocean Service, Scituate, \\ Massachusetts
}

Follow this and additional works at: https://digitalcommons.unl.edu/usdeptcommercepub

Part of the Environmental Sciences Commons

Clapham, P J.; Aguilar, Alex; and Hatch, Leila, "Determining spatial and temporal scales for management: lessons from whaling" (2008). Publications, Agencies and Staff of the U.S. Department of Commerce. 160.

https://digitalcommons.unl.edu/usdeptcommercepub/160

This Article is brought to you for free and open access by the U.S. Department of Commerce at DigitalCommons@University of Nebraska - Lincoln. It has been accepted for inclusion in Publications, Agencies and Staff of the U.S. Department of Commerce by an authorized administrator of DigitalCommons@University of Nebraska - Lincoln. 


\title{
Determining spatial and temporal scales for management: lessons from whaling
}

\author{
Phillip J. ClaPham \\ National Marine Mammal Laboratory, \\ Alaska Fisheries Science Center, \\ 7600 Sand Point Way NE, \\ Seattle, Washington 98115, U.S.A. \\ E-mail: phillip.clapham@noaa.gov \\ Alex Aguilar \\ Department of Animal Biology, \\ Faculty of Biology, \\ University of Barcelona, \\ 08071 Barcelona, Spain

\section{LEILA T. HATCH} \\ Gerry E. Studds Stellwagen Bank National Marine Sanctuary, \\ National Ocean Service, \\ Scituate, Massachusetts 02066, U.S.A.
}

\begin{abstract}
Selection of the appropriate management unit is critical to the conservation of animal populations. Defining such units depends upon knowledge of population structure and upon the timescale being considered. Here, we examine the trajectory of eleven subpopulations of five species of baleen whales to investigate temporal and spatial scales in management. These subpopulations were all extirpated by commercial whaling, and no recovery or repopulation has occurred since. In these cases, time elapsed since commercial extinction ranges from four decades to almost four centuries. We propose that these subpopulations did not recover either because cultural memory of the habitat has been lost, because widespread whaling among adjacent stocks eliminated these as sources for repopulation, and/or because segregation following exploitation produced the abandonment of certain areas. Spatial scales associated with the extirpated subpopulations are frequently smaller than those typically employed in management. Overall, the evidence indicates that: (1) the time frame for management should be at most decadal in scope (i.e., $<100 \mathrm{yr}$ ) and based on both genetic and nongenetic evidence of population substructure, and (2) at least some stocks should be defined on a smaller spatial scale than they currently are.
\end{abstract}


Key words: management units, population structure, whaling, recovery, whales.

In terms of sheer biomass, the commercial hunting of whales in the 20th century represents one of the greatest wildlife exploitation episodes in human history. Between 1904 and 2005, more than two million whales were killed in the Southern Hemisphere alone (Clapham and Baker 2002). The International Convention for the Regulation of Whaling, signed in December 1946, established the International Whaling Commission (IWC) to oversee management-related research on whale stocks and to set quotas that would not exceed sustainable levels of exploitation. This objective, however, was clearly nominal at best: For most of the century, catch levels were invariably excessive, and populations of several species were reduced to very low levels. In a number of cases, local subpopulations appear to have been completely extirpated.

The IWC quotas are set for specific "stocks," which do not necessarily equate to genetic subpopulations but rather refer to spatial groupings of whales that are convenient for the purpose of management (Donovan 1991). Selection of the appropriate management unit is critical to the conservation of a subpopulation. For example, if two distinct subpopulations subject to anthropogenic removals are managed as a single unit, and if the removals are similar in their numbers for both subpopulations but one is smaller than the other, the risk that the former subpopulation will be lost is substantially increased because the impact of mortality in it will be underestimated (see Taylor 1997). A similar risk may occur if the two subpopulations are of similar size, but the bulk of the removals occurs in only one of them. This process is identical to the well-known case of multispecies fisheries, in which the risk of overexploiting a scarce species is proportionally much higher than for the species that predominates in the catch, making these operations more risky than those directed at a single target species. Thus, in single-species fisheries, or in a whaling operation exploiting a single subpopulation, catch per unit effort rapidly reflects overexploitation, and the increased costs of obtaining a given catch discourages fishers to continue exploitation; the resource reaches "commercial extinction" before "biological extinction" takes place. This process does not occur in a multispecies or a multistock fishery because catches may continue indefinitely on the basis of the profits obtained from the more abundant species or subpopulation, while negligible but sustained catches would continue on the scarcer species or stock and eventually bring it to extinction. An accurately defined management unit is thus the key to avoiding extirpation of subpopulations or local forms.

If the animals inhabiting a specific area are severely reduced in number, repopulation may occur from a remnant (founder) stock and/or by immigration from adjacent areas. However, the remnant stock may be too small to be viable, and distance or other factors may limit or preclude recolonization from the nearest viable subpopulation. Because of this, management should be based upon units that confer the maximum protection and minimize the possibility of local extirpation. Despite the importance of this principle, management has extensively disregarded it, mostly because of the technical (and sometimes political) difficulties of establishing such discrete units. Thus, the "management unit" will not necessarily be synonymous with a biological subpopulation, or even a "genetic" population, a distinction that is now commonly recognized by conservation biologists (e.g., Donovan 1991, Bossart and Prowell 1998, Moritz and Faith 1998, Taylor and Dizon 1999, Taylor 2005). 
Whaling has significantly reduced many subpopulations of large cetaceans. Although in some cases such reductions are recent, in many others the decline occurred long ago, sometimes several centuries ago. The demographic trajectories of the affected subpopulations have been variable: some never recovered but others have increased to approach their original abundance. Reasons for this apparently varying resilience are in most cases unclear, but they are very probably strongly related to the manner in which removals impacted the subpopulation and its social structure.

Although commercial whaling clearly represents a failure of management, some of the exploitation events themselves can be viewed as a series of unintended but highly informative experiments on the consequences of overhunting. Here, we examine eleven cases in which putative subpopulations of whales in particular areas were extirpated or severely reduced by whaling, and where no significant repopulation or recovery has occurred on a management time frame. We extract commonalities from them and discuss the potential implications of such events for the demographics and genetics of baleen whale populations. We also consider the information that the extirpation events provide regarding the importance of temporal and spatial scale in designing management units for baleen whales and other species.

\section{METHODS}

The five species involved in the examples summarized below include the humpback whale (Megaptera novaeangliae), the blue whale (Balaenoptera musculus), the fin whale (Balaenoptera physalus), the bowhead whale (Balaena mysticetus), and the North Atlantic right whale (Eubalaena glacialis). The hunting histories of these species are varied. Commercial fisheries for right and bowhead whales began in mediaeval times and were largely exhausted by 1900 . In contrast, neither blue nor fin whales were hunted on a consistent basis until the advent of modern whaling (roughly speaking, the end of the 19th century), when the introduction of steam-powered catcher vessels and explosive harpoons allowed whalers to effectively pursue even the fastest whales. Humpback whales were hunted sporadically prior to the modern era, at which time they were frequently the first species to be overexploited whenever whaling operations expanded to new areas.

We have not used North Atlantic gray whales (Eschrichtius robustus) as a case study for the purpose of this paper because, although they became extinct in the North Atlantic only recently (perhaps by 1800, Mead and Mitchell 1984), there is no substantial evidence that this extinction was caused by whaling (Clapham and Link 2006). We also did not consider bowhead whales (Balaena mysticetus) off Labrador, even though genetic analysis of thirteen whale humeri recovered from 17 th century Basque whaling sites in Red Bay (Cumbaa 1986) has demonstrated that all but one of the bones belonged to that species (Rastogi et al. 2004), which is only very rarely observed in this region today. Two reasons account for the exclusion of this casestudy population. On the one hand, it is not known whether the bones analyzed are representative of the catch composition of that early fishery because right whales, a primary target for the Basques elsewhere and now present in the area, were also widely hunted. On the other, the Basque fishery occurred during a markedly colder period (the so-called "Little Ice Age"), and it is likely that the geographical range of the bowhead whale has shifted to the north since then (Rastogi et al. 2004). Consequently, although we are unable to rule out extirpation by whaling as a contributing factor 
to the bowhead's absence from Labrador today, the main cause of the current rarity of the species in the area is more likely to be environmental in nature.

Catch data for this paper were drawn from published papers as well as from records of the Bureau of International Whaling Statistics. Uncertainties regarding catch figures vary by fishery and by area, and are identified below; in general, there is considerably more uncertainty associated with historical (i.e., premodern) hunts, for which records are inevitably incomplete. However, the accuracy of the overall catch totals is less important than establishing when each fishery reached the point of commercial extinction.

This latter term is subjective and can be defined in several ways. An extreme definition would be the year in which the last whaling vessel made a profit from a take of the subpopulation in question, no matter how few the numbers of whales involved; an example is four bowheads killed off Spitsbergen by a Norwegian whaler in 1932 (Reeves 1980). However, because such isolated opportunistic catches always occurred long after the subpopulation concerned had crashed and ceased to be a primary target of whaling operations, it seems more reasonable to adopt a definition that reflects what we term here the "terminal decline" of the affected stock. Fixing this point is necessarily a somewhat subjective and arbitrary exercise, particularly for historical fisheries for which accurate catch data are lacking. For the purpose of this paper, we have used the date at which the whaling operations in question abandoned a particular subpopulation as a principal (as opposed to an occasional opportunistic) target. In some cases (such as fin whales off Gibraltar), the collapse and complete cessation of a fishery occurred in a short and clearly identifiable time; in others, we have had to employ a certain degree of judgment in fixing the date of terminal decline. We use the latter term synonymously with "commercial extinction."

The term "recovery" is used here in a general sense. Quantitative definitions (for example, the lower end of optimum sustainable population size) are needlessly precise and would not fit all of the case studies described below. Rather, we use "recovery" to describe a subpopulation that has rebounded from overexploitation and in which whales appear to be generally abundant and increasing in number, rather than scarce and static.

\section{RESULTS}

For each example below, we briefly review the background to the fishery, as well as what is known of catch history and the point of terminal decline; a summary is given in Table 1. We also summarize the current status of the subpopulation as indicated by recent surveys or other sources.

\section{Humpback Whales off South Georgia}

South Georgia was a major feeding ground for several species of whale from Antarctic Area II (for a depiction of the six baleen whale management areas in the Antarctic, see IWC 1980, p. 582); large catches of balaenopterids were made there beginning in 1904. As was frequently the case elsewhere in the world, humpback whales were the first species to be overexploited off South Georgia. The speed with which their local extirpation was accomplished was remarkable: Although the first catches were not made until 1904, by 1915 the species was commercially extinct in the area (Moore et al. 1999). The Bureau of International Whaling Statistics reports a total of 21,016 


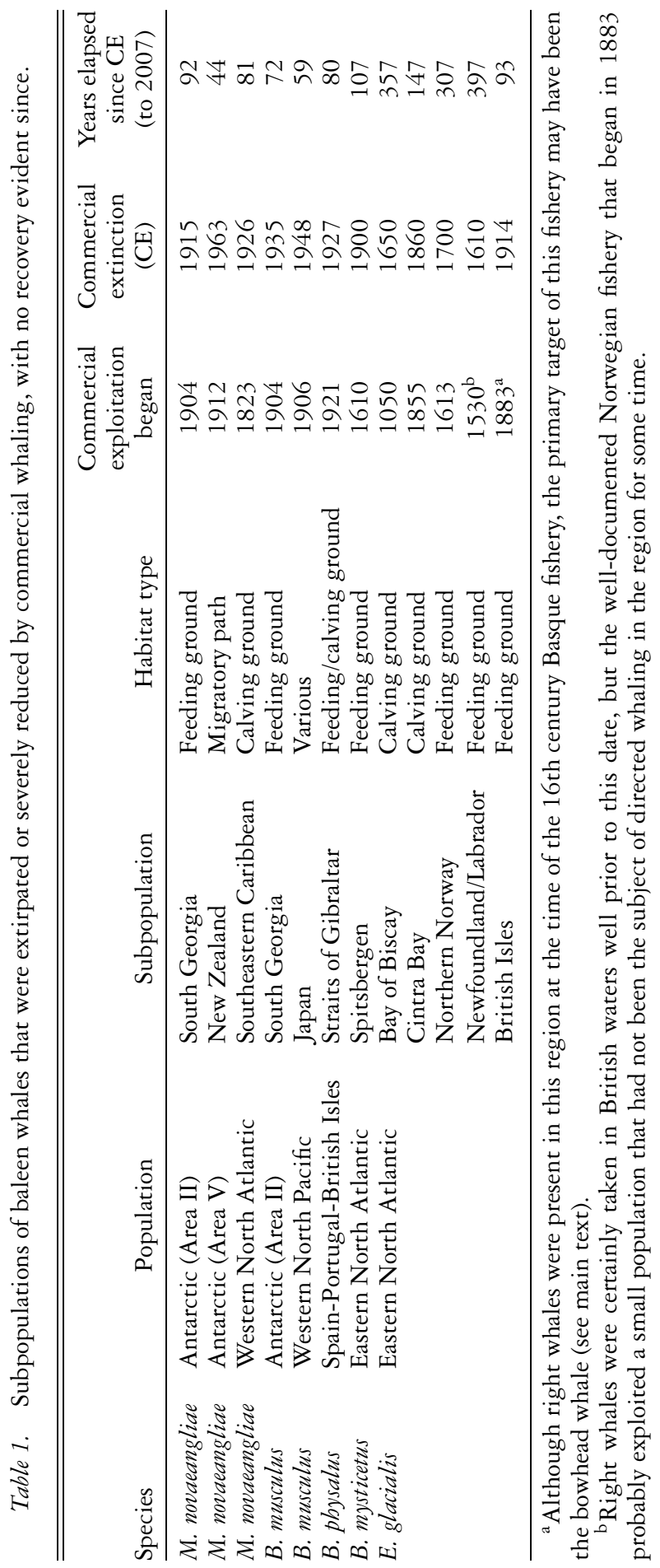


humpbacks taken at South Georgia between 1909 and 1955, with the majority of these catches $(18,557)$ made prior to 1916 . Small numbers of humpbacks were killed at South Georgia in various years thereafter (the largest reported annual take was one of 238 whales in the 1945/1946 season), with zero recorded catches from 1955 on. It is important to note that the catch figures summarized below do not include extensive illegal takes by the USSR (Yablokov et al. 1998). The USSR killed more than 48,000 humpbacks in the Southern Hemisphere between 1948 and 1971, yet reported fewer than 3,000 of these takes. Although overall totals for these catches have been published (Zemsky et al. 1995, Yablokov et al. 1998), location data for many catches remain incomplete; however, it is not thought that the humpback whales were taken by the USSR off South Georgia, although small numbers were killed by the factory fleet Yuri Dolgorukiiy several hundred miles to the north, on what may have been a migratory route to and from this feeding ground.

Despite the continued occurrence of a prey base of krill in the region, recent surveys of the South Georgia area have recorded very few sightings of humpbacks (Moore et al. 1999), and whale observations recorded by a local whale museum contain very few records of this species. ${ }^{1}$

\section{Humpback Whales off New Zealand}

The waters off New Zealand were a major migratory pathway for humpback whales, probably for those from the eastern portion of the Area V stock (Dawbin 1966). Between 1912 and 1963, many shore stations operated around New Zealand, taking a recorded total of 5,224 humpback whales; the peak catch in later years was 226 whales in 1960 , with a rapid decline thereafter (Ell 1995). A recent disclosure that the USSR took some 25,000 humpbacks in just two seasons (1959/1960 and 1960/1961), and mostly from the high-latitude waters south of Australia, New Zealand, and western Oceania (Mikhalev 2000, 2004), provides a clear explanation for the crash of the New Zealand stock in 1960. Although a few sightings of humpbacks have been made in New Zealand waters in recent years, the species remains comparatively rare in the region (Gibbs and Childerhouse 2000). Furthermore, compared to the late 1950s, humpback whales are today seen in only very low numbers in Fiji, which was likely one migratory destination of the whales passing New Zealand (Gibbs et al. 2006).

\section{Humpback Whales in the Southeastern Caribbean}

The southeastern Caribbean appeared to have been the primary breeding ground for North Atlantic humpbacks in the 19th century, as evidenced by the large catches made there by Yankee whalers. Reeves et al. (2001) examined logbooks and journals of American whaling ships operating in the West Indies during this time and found records of more than 2,400 humpback whales killed or sighted in the southeastern Caribbean during forty-eight documented voyages. Although no large catches have occurred there since 1926, the abundance of humpbacks remains surprisingly low in the area. Between 16 February and 29 March 2000, Swartz et al. (2003) conducted a visual and acoustic survey of most of the Lesser Antilles, Trinidad, Tobago, the Gulf of Paria, and much of the coast of Venezuela. They recorded only 33 sightings of 46 humpback whales, most of which were detected acoustically before being seen.

\footnotetext{
${ }^{1}$ Personal communication from Ari S. Friedlaender, Duke University Marine Laboratory, 135 Pivers Island Road, Beaufort, North Carolina 28516, U.S.A., May 2006.
} 
Although this could imply that the subpopulation remains small and is largely separate from others in the North Atlantic, this seems unlikely given the known movements of humpbacks throughout the West Indies, and the recent record of a photoidentified animal observed off both Greenland and Grenada (Stevick et al. 1999). In contrast to the 19th century, the major concentration of humpback whales in the Caribbean region today is found not in the southeastern portion but in the northern West Indies, north of Hispaniola; this apparent shift is discussed further below.

\section{Blue Whales off South Georgia}

The total catch of blue whales at South Georgia between 1909 and 1962 was 41,026, of which 39,296 were taken prior to 1936. In several years, more than 3,000 blue whales were killed in a single season, with the highest catch being of 3,689 animals in 1926/1927. As with humpback whales from the same region, above, these figures do not include unreported Soviet catches during 1948-1971 (Yablokov et al. 1998), although there is currently no evidence that the USSR was operating in this area. Recent surveys have found negligible sightings of blue whales in the region (Moore et al. 1999; S. Reilly, unpublished data). Whether the whales from South Georgia were part of the same population as those off the southwestern coast of Africa is not clear; catches in the latter area were also extensive, and few whales are observed there today.

\section{Blue Whales off Japan}

The relationship of the subpopulation of blue whales that once inhabited Japanese coastal waters to others in the North Pacific is unknown. Although the IWC considers the whole North Pacific as one management unit (Donovan 1991), Reeves et al. (1998) have proposed that up to five subpopulations may occur in this ocean. However, based on limited marking data (Ohsumi and Masaki 1975), and on patterns in the timing of catches, T. Kasuya (personal communication, March 2000) speculates that a single stock wintered off the Pacific coast of southern and western Japan, and extended its range north in summer.

Blue whales were taken by modern whaling methods off Japan and in nearby waters (including off the Korean Peninsula and in the Kuril Islands) beginning in about 1900. In all, sixteen shore stations were operating at various times between 1906 and 1949, with detailed records available from 1911 on (Kasahara 1950, Kasuya 2002). Although blue whales were killed at all sixteen stations (a total recorded take of 1,248 whales), the majority of catches ( $>1,000$ animals) occurred at four stations along the Pacific coast of Honshu and off eastern Hokkaido (Kasahara 1950). To these figures must be added unrecorded catches between 1906 and 1910, as well as a minimum of forty-seven blue whales taken by net fisheries from 1698 to 1896 (Kasuya 2002).

It is difficult to determine when this subpopulation became commercially extinct. Only small numbers of blue whales were taken off southern Honshu after about 1922, while catches off northeastern Honshu and eastern Hokkaido remained substantial until the late 1940s; for the purpose of this paper, we have somewhat arbitrarily taken 1948 as the point of terminal decline. However, that the subpopulation was eventually extirpated seems clear: Extensive sighting surveys in this region in recent years have recorded no blue whale sightings at all (Miyashita et al. 1995). 


\section{Fin Whales off Gibraltar}

Fin whales were exploited and apparently extirpated off the Straits of Gibraltar early in the twentieth century. Catches were made throughout the year with no apparent seasonality, suggesting a local, nonmigratory subpopulation (Sanpera and Aguilar 1992). There are no data regarding the relationship of this stock to other fin whale subpopulations in the North Atlantic or the Mediterranean (see Bérubé et al. 1998 for a review).

During the period 1921-1926, a minimum of 4,170 fin whales were taken from one shore station and one land-based floating factory (Sanpera and Aguilar 1992, Aguilar 2006). This total does not include the activity of another, poorly documented operation by another floating factory that visited the region on two occasions (19231924) and that comprised an additional catch of at least 150 whales. The whales were caught on the Atlantic side of the Straits of Gibraltar and were found in dense concentrations in a small area located west and south of the mouth of the Straits. They were so close to shore that, in the first season, one of the two catcher boats put into work to service the land factory had to remain anchored because the station was unable to process more whales than those caught by a single vessel. The processing capacity was rapidly increased and catch numbers skyrocketed. In 1923 the oil production was 19,236 barrels per catcher boat, one of the highest values ever recorded (Tønnessen and Johnsen 1982), thus reflecting a remarkable density of fin whales in the area. By 1927, the subpopulation had crashed: catch per unit effort abruptly declined from a maximum of fifty-four whales per boat per month in 1922 to only six per boat per month at the end of the period (Aguilar 1985, Sanpera and Aguilar 1992). Attempts to revive the fishery following World War II were of limited success, and profits were based upon catches of sperm whales, although fin whales continued to be taken whenever found. Over a 26-yr period (1933-1959), 450 fin whales were caught, but catch rates progressively declined to negligible levels at the end of the period; only four fin whales were caught in 1958 and none in 1959. The following year the fishery was abandoned.

Since 1960, when scientists started work in the region, no strandings have been recorded either in Spain or in Morocco, and the few sightings (fewer than ten) have all been made inside the Straits but none in the area where fin whales were originally clumped (Bayed 1996, Raga and Pantoja 2004). These sightings may represent either stragglers from the Mediterranean subpopulation or remnants of the once-abundant Gibraltar Straits subpopulation.

\section{Bowhead Whales off Spitsbergen}

The bowhead whale occurs only in the Northern Hemisphere and has a circumpolar distribution; the species is closely associated with sea ice (Shelden and Rugh 1995). In the eastern (Atlantic) Arctic, three subpopulations are tentatively recognized: Hudson Bay, Davis Strait, and Spitsbergen (although there has been some recent debate within IWC about whether the first two constitute a single stock). Historically, the Spitsbergen subpopulation is thought to have encompassed an area including the Barents Sea, Spitsbergen, and the Greenland Sea (Moore and Reeves 1993).

The commercial fishery for bowheads on the Spitsbergen feeding grounds and in adjacent waters began in 1610, and the preexploitation stock size has been estimated (on typically questionable historical data) at between 25,000 and 100,000 animals (Reeves 1980, Allen and Keay 2006). By 1670, land stations at Spitsbergen were 
forced to close because of the paucity of whales in coastal waters (de Jong 1983). Pelagic operations continued to take the species in the region, although catch per unit effort declined from 16.8 whales per vessel in the period 1800-1809 to 1.7 whales per vessel between 1850 and 1859. Only eighty-five bowheads were caught in the region in the decade prior to 1890 , and the few bowhead catches made after this were largely incidental to those of other species (Gray 1929, Reeves 1980). We have arbitrarily fixed the year 1900 as the point of commercial extinction for this subpopulation.

Various authors have commented on the effective extinction of the Spitsbergen bowhead stock, as evidenced by the paucity of modern sightings from surveys and whaling operations (Reeves 1980, Jonsgård 1982, McQuaid 1986, Wiig 1991, Christensen et al. 1992, De Korte and Belikov 1994, Wiig et al. 2007). The few animals that are occasionally observed in the region presumably constitute either a remnant and functionally extinct subpopulation, or perhaps stragglers from one of the larger subpopulations in the western North Atlantic (Jonsgård 1982). Christensen et al. (1992) suggest that the present subpopulation numbers "in the tens" of animals. The combined current size of the Hudson Bay and Davis Strait stocks is in dispute, although it appears to be well below preexploitation levels (Clapham et al. 1999); however, the lack of recovery of the bowhead whale in the Spitsbergen region this century strongly suggests that little exchange occurs between this subpopulation and those to the west.

\section{Right Whales in the North Atlantic (Five Subpopulations)}

The preexploitation range of the right whale in the North Atlantic extended from Europe and western Africa to North America and Greenland (Reeves and Mitchell 1986). The extant subpopulation, which numbers approximately 300 animals and is declining, is largely confined to North American waters (IWC 2001).

Systematic whaling for this species began as early as the 11 th century when the Basques established a coastal fishery in the Bay of Biscay (Aguilar 1981, Reeves and Mitchell 1986). The fishery expanded to Labrador and Newfoundland no later than 1530 (Barkham 1984, Aguilar 1986, Cumbaa 1986) and, probably around 1613, to Iceland and northern Norway (Smith et al. 2006). Furthermore, as noted above, recent genetic analysis of bones recovered from Basque whaling sites in Labrador have suggested that this may have been primarily a bowhead whale fishery (Rastogi et al. 2004), although this matter remains unresolved and right whales were clearly not absent from the region.

Right whales were hunted off New England and elsewhere off the eastern coast of the United States beginning in the 17th century. In the 1800s, Yankee pelagic whaling exploited the species off Greenland (the Cape Farewell Ground), as well as at Cintra Bay off the western coast of Africa (Reeves and Mitchell 1986). The latter appears to have been a calving ground, possibly for the European subpopulation.

It is not clear when the eastern North Atlantic subpopulation of right whales reached the point of terminal decline. Historical records suggest that this may have occurred by about 1650 in the Biscay region, which included the coast from Biarritz in France to Galicia in Spain, and by about 1700 in the northern Norway region (Aguilar 1981, 1986; Smith et al. 2006; Table 1). The subpopulation off the Labrador and Newfoundland coasts first showed signs of decline about 1610, and the last recorded catch was in 1713 (Aguilar 1986). The Cintra Bay ground was worked by American 
pelagic whalers at various times between 1855 and 1880, and the subpopulation had apparently been severely depleted by 1860 (Reeves and Mitchell 1986). The remnant northern European stock appears to have been extirpated by sporadic catches in northern Norway up to the 19th century (Lindquist 1994) and in the Bay of Biscay up to 1904 (Aguilar 1986), as well as by modern-type coastal whaling that operated at various times from 1881 to 1924 off the British Isles (mainly western Scotland and Ireland). Terminal decline in this region seems to have been reached around 1914 (Collett 1909, Brown 1976).

Whaling off both Iceland and Greenland appears to have extirpated local subpopulations of right whales in the 19th century (Reeves and Mitchell 1986), although the relationship of these stocks to other segments of the North Atlantic subpopulation is unknown, and we have not included them in discussions here.

Today, North Atlantic right whales are found largely in a restricted range from the southeastern United States (the only known calving ground) to Nova Scotia (Kraus et al. 1986, IWC 2001). Sightings elsewhere are extremely rare, especially in the northeastern North Atlantic (Brown 1986, IWC 2001, Jacobsen et al. 2004, Smith et al. 2006). One identified individual from the western North Atlantic was seen recently to move to northern Norway, and then return back to the North American coast (Jacobsen et al. 2004). Cintra Bay has been surveyed only once in recent years and no right whales were found (Notarbartolo di Sciara et al. 1997).

\section{DISCUSSION}

Some baleen whale subpopulations have successfully recovered from the extreme reduction caused by exploitation. The eastern North Pacific gray whale and several subpopulations of southern right whales and of humpback whales from both hemispheres, all of which were commercially extinct in the late 19th or early 20th centuries, are today well recovered or show consistent demographic growth (Reilly 1992, Clapham et al. 1999, Best et al. 2001). The mechanisms promoting recovery are not clear, but the process is undoubtedly not static. In cases where whaling pressure was concentrated in a small area, as typically occurred in land-based operations, local depletion could be compensated by redistribution of individuals from neighboring waters. Whenever a subpopulation was decimated or eliminated, recovery could also be the result of immigrants from other subpopulations moving to the newly available habitat. $^{2}$

Conversely, many subpopulations of baleen whales have never recovered from past exploitation. In several cases, absence of population growth may be attributed to continuing low levels of take that impeded demographic growth. This may be the case for western North Atlantic right whales (estimated at 300 animals, with high mortality from ship collisions and fishing gear entanglements [Kraus et al. 2005]); right whales off Tristan da Cunha (subject to extensive illegal Soviet catches in the 1960s [Best 1988]); western North Pacific gray whales, (estimated at 100 animals, with catches as recently as the 1960s [Kato and Kasuya 2002, Weller et al. 2002] and continued fisheries bycatch and direct take off Japan today); and eastern North Pacific right whales (no good abundance estimate available, but clearly very small, with large illegal Soviet catches in the 1960s [Brownell et al. 2001]).

\footnotetext{
${ }^{2}$ With sufficient samples and appropriate genetic markers, it should be possible to distinguish this scenario from one in which a depressed and isolated local population has rebounded on its own.
} 
However, in many cases, recovery did not take place despite discontinuation of hunting pressure. The cause for the absence of demographic growth in these cases is unknown. Availability of prey, which is highly determinant of demographic growth, appears unlikely to be a reason given that large-scale removals of predators should (at least initially) reduce predation pressure on a resource; this is consistent with recent data from South Georgia, where surveys have found abundant euphausiids, yet neither humpback nor blue whales have returned to the area (Moore et al. 1999). It is possible that the removal of key species precipitated an ecosystem shift, which subsequently made it more difficult for the exploited species to reinvade, but there is currently no evidence that this was the case with baleen whales.

Another hypothesis to consider is whether habitat loss or encroachment has caused abandonment of a given territory. The only case in which this seems plausible is that of fin whales off Gibraltar, where large increases in shipping occurred in the 20th century. The validity of this explanation is unknown, but it should be noted that the main aggregation of whales occurred at some distance from the mouth of the Straits where traffic concentrates (Aguilar 2006) and also that other subpopulations of fin whales continue to inhabit areas subject to comparatively high densities of vessel traffic (e.g., those in the southern Gulf of Maine or the Ligurian Sea).

The examples examined in the present paper collectively indicate that, when subpopulations of whales within relatively small geographic areas are extirpated or greatly reduced, no repopulation of the area occurs by immigration from adjacent subpopulations. Three factors (separately or in combination) may play roles in such nonrecoveries. The first may be a loss of "cultural memory." From the subpopulations reviewed here, it can be seen that the lack of recovery can involve breeding grounds (e.g., right whales at Cintra Bay), feeding areas (e.g., humpback and blue whales at South Georgia), or migratory routes (humpbacks off New Zealand). The timescale since extirpation ranges from four decades in the case of New Zealand humpback whales to several centuries for European right whales or Spitsbergen bowhead whales. We suggest that the root cause of this phenomenon lies in a "cultural memory" about the existence of a particular habitat, a memory that is extirpated together with the whales. Such cultural transmission would be mediated by strong maternally directed fidelity to specific habitats, as has been observed in some balaenopterids (Clapham and Mayo 1987, Clapham and Seipt 1991).

A second factor, which would strengthen the effect of the loss of "cultural memory," is the excessive exploitation of whales from adjacent regions, which might otherwise have provided a source for repopulation of the area in which extirpation had occurred. Very few of the extirpation events described above were conducted in isolation. For example, the huge catches of humpback and blue whales at South Georgia were part of large-scale removals throughout the Southern Ocean. Accordingly, there may be little incentive today for whales from adjacent areas to roam and "discover" South Georgia if abundance is low everywhere and resources are locally abundant. Processes similar to this are likely to have occurred in other areas: in the Gibraltar Straits grounds, where the local fin whale subpopulation was extirpated and the neighboring subpopulations off Portugal and northwestern Spain were subsequently subject to intense exploitation (Sanpera and Aguilar 1992, Aguilar 2006); in New Zealand waters, where occurrence of humpback whales has continued to be low despite the strong subpopulation growth of the Area $\mathrm{V}$ stock, of which the humpbacks migrating past New Zealand may have been a part (Gibbs and Childerhouse 2000); in the Spitsbergen bowhead whale grounds that have not been repopulated despite the existence of a relatively robust 
subpopulation in Hudson Bay and Davis Straits (Zeh et al. 1993); in the eastern North Atlantic waters originally occupied by right whales, which have not been recolonized by the western North Atlantic subpopulation despite the documented recent movement of a western whale to the waters of Norway (Jacobsen et al. 2004); and in the waters off Japan, which have not been repopulated by blue whales from elsewhere in the North Pacific where they still occur in measurable densities.

A third factor that is also likely to play a role in nonrecovery is social structure. A plausible example concerns the humpback whales of the southeastern Caribbean. Although whaling catch data from the 19th century show that this area hosted the largest aggregation of the species in the North Atlantic (Reeves et al. 2001), humpback whales have failed to increase in this region in recent decades despite strong population growth throughout the North Atlantic. However, rather than this being a true extirpation, this example may represent a socially mediated shift in distribution. We agree with Reeves et al. (2001) that, because of the characteristics of the humpback's mating system (see review in Clapham 1996), there is likely to be only one major aggregating point in any breeding range. They suggest that, following the overexploitation of the 19th century, this focal point may have shifted to the northern West Indies, where densities of humpbacks are today at least two orders of magnitude greater than in the southeastern Caribbean (Winn et al. 1975, Mattila et al. 1994). Reaggregation of breeding humpback whales following an exploitation event would likely be a stochastic process and would be facilitated by the considerable range over which humpback songs (produced by males during the breeding season, Tyack 1981) can be heard. Whether the relatively recent use of Hawaii as a breeding ground for North Pacific humpback whales (see Herman 1979) represents another shift in distribution following depletion elsewhere is unclear.

The list of case studies we have used here is likely not exhaustive. For example, blue whales were drastically reduced to less than $1 \%$ of their estimated preexploitation abundance throughout the Southern Ocean (Branch et al. 2007), with some 369,000 taken in the 20th century (Clapham and Baker 2002). Although overall they may be slowly increasing in numbers (Branch et al. 2007), their return to specific former habitats (like South Georgia or the southwestern coast of Africa) may not be occurring, decades after exploitation ceased.

However, it is also important to acknowledge that apparent lack of recovery in subpopulations of whales may in some cases reflect a lack of, or insufficient, survey effort. When combined with very low abundance, this would lead to very low statistical power to detect any increasing trend.

\section{Implications for Management}

The examples described in this review indicate that management units for large whales will not necessarily conform to some commonly employed definitions of the term "population." A prominent example is that currently given by the U.S. Marine Mammal Protection Act (MMPA 1972), which defines a population as:

"A group of marine mammals of the same species or smaller taxa in a common spatial arrangement which interbreed when mature."

Using this definition, one could imagine protecting whales in a common mating ground, where animals interbreed, but not regulating takes from the feeding areas to which they migrate. However, it is apparent from the feeding ground examples de- 
scribed above that the subpopulations in such areas could be wiped out with little hope of regional recovery. A particularly well-studied example is that of humpback whales in the North Atlantic, which segregate to specific summer feeding areas but mix on a common breeding ground in the West Indies in winter (Katona and Beard 1990). Maternally directed fidelity to these feeding grounds is extremely strong (Clapham and Mayo 1987) and appears to persist over an evolutionary timescale in at least some areas (Palsbøll et al. 1995, Larsen et al. 1996). Accordingly, management based only upon protection of the West Indies breeding area would be insufficient because extirpation of any of the feeding ground subpopulations would not likely be followed by repopulation over any period meaningful to management. Such a loss would also run counter to the intent of the U.S. MMPA, which requires managers to maintain subpopulations as "functioning elements" of their ecosystems. For the purposes of management, a stock is recognized as a demographically independent subpopulation where births and deaths within the subpopulation (internal dynamics) are far more important to maintaining the subpopulation than immigration from neighboring subpopulations (external dynamics) (Wade and Angliss 1997). Given this definition of a management unit together with the above-mentioned maternally directed fidelity to feeding grounds, the maternally inherited genetic marker (mitochondrial DNA) could correctly identify demographically independent subpopulations of North Atlantic humpback whales, whereas nuclear DNA would lead to a false conclusion of no differentiation between many feeding grounds and potentially lead to extirpations.

Irrespective of whether other factors contribute to lack of recovery following overexploitation, the independence in trajectories of vicinal subpopulations of baleen whales is manifest in smaller stock units than those that are often delineated for management ( $c f$. baleen whale stock divisions in IWC 1980, pp. 581-582). This is supported by some recent genetic analyses; for example, the finding of significant subpopulation differentiation among humpback whales in Oceania (Olavarría et al. 2007). We therefore suggest that management of whale populations should be based upon any unit that, if extirpated, would not recover by any mechanism within a management time frame. Based upon the examples given here, we further suggest that: (1) the time frame for management should be at most decadal in scope (i.e., $<100 \mathrm{yr}$ ) and based on both genetic and nongenetic evidence of population substructure, and (2) stocks should be defined on a smaller scale than they currently are and that the geographical limits of the stocks should be established within a regional, ecosystem-based spatial framework.

This study documents failures by the IWC and individual whaling nations to accurately identify the timescale over which whale management units should be defined. In order to learn from these mistakes, such management units should be defined using timescales that are: (1) appropriate to assessing management successes and failures (meeting the mandates of national and international protective and resource management statues), and (2) associated with the appropriate paradigm for defining populations. Should international commercial whaling governed by the IWC resume, success of management actions to sustainably exploit populations would be monitored and readdressed by this body on an annual basis. Under legislation governing species in U.S. waters, the success of management actions to recover endangered marine mammal species, protect all marine mammals, and allow sustainable rates of aboriginal take for a few Arctic species are largely monitored and readdressed by government agencies annually. Thus, although many long-term management goals often cannot be achieved over short periods of time (e.g., ensuring a population's ability to adapt to future environmental change or ensuring a population's persis- 
tence throughout its native range), success toward these goals is gauged more or less continuously.

In defining subpopulations, two paradigms are commonly employed, which can be broadly classified as evolutionary and ecological (Waples and Gaggiotti 2006). The former is most commonly focused on the interplay of different evolutionary forces (including rates of gene flow, selective pressure, and drift through isolation) over thousands of years, resulting in evolutionarily significant subdivision within species. In contrast, ecologically meaningful subpopulations (those that may be less permanent or that reflect more recent structuring of subpopulations) remain challenging to characterize using genetic data, despite being of the highest relevance over the decadal timescales that we recommend should be adopted for management. Although the use of genetic data to estimate contemporary gene flow remains an active area of theoretical development, current models are computationally intensive and often biologically unrealistic (Waples and Gaggiotti 2006). Thus, integrating information from multiple lines of evidence remains a more universally applicable approach to characterizing ecologically meaningful management units (Dizon et al. 1992, Taylor et al. 1997, Paetkau 1999, Zannèse et al. 2006). We recommend that the data collected using behavioral, marking, tagging, and acoustic techniques should be integrated with genetic analyses to avoid missing short-term demographic discontinuities with potentially long-term adverse repercussions on the survival of subpopulations.

This review also documents failures to accurately identify the spatial scales over which whale management units are defined. Therefore, as with the temporal scales noted above, management units should be defined using spatial scales that can be judged against the requirements of relevant national and international management statutes, and that are associated with the appropriate paradigm for defining ecosystems. ${ }^{3}$

\section{ACKNOWLEDGMENTS}

We thank Martine Bérubé, Mike Donoghue, Toshio Kasuya, Michael Moore, and Steve Reilly for supplying information and references for this paper. Thoughtful reviews by Scott Baker, Trevor Branch, Tony Martin, Richard Merrick, Howard Rosenbaum, Fred Serchuk, Barb Taylor, and Robin Waples greatly improved the manuscript.

\section{LITERATURE CITED}

Aguilar, A. 1981. The black right whale, Eubalaena glacialis, in the Cantabrian Sea. Report of the International Whaling Commission 31:457-459.

Aguilar, A. 1985. Biología y dinámica poblacional del rorcual común (Balaenoptera physalus) en las aguas Atlánticas ibéricas. Ph.D. dissertation, Faculty of Biology, University of Barcelona, Barcelona, Spain, 487 pp.

${ }^{3}$ Currently, protected species statutes are the most prominent management tools utilized by the U.S. government, the IWC, and the United Nations to regulate impacts specific to marine mammals. Although species-specific, these statutes include strong area-specific mandates, including the protection of critical habitat, and maintenance of species as "functional elements of their ecosystems." Growing scientific understanding of the complexity of the relationship between and among species and their local environments is leading some governmental agencies to deemphasize species-specific management in favor of regional and/or ecosystem-based approaches (National Oceanic and Atmospheric Administration 2005). 
Aguilar, A. 1986. A review of old Basque whaling and its effect on the right whales (Eubalaena glacialis) of the North Atlantic. Report of the International Whaling Commission (Special Issue 10):191-199.

Aguilar, A. 2006. Catches of fin whales around the Iberian Peninsula: Staitistics and sources. International Whaling Commission doc. SC/14/FW/17-SC/M06/FW17, 12 pp. (Available from IWC, The Red House, 135 Station Road, Impington, Cambridge CB24 9NP, U.K.)

Allen, R. C., AND I. KeAY. 2006. Bowhead whales in the Eastern Arctic, 1611-1911: Population reconstruction with historical whaling records. Environment and History 12:89-113.

BARKHAM, S. H. 1984. The Basque whaling establishments in Labrador 1536-1632-a summary. Arctic 37:515-519.

BAYED, A. 1996. First data on the distribution of cetaceans along the Moroccan coasts. European Research on Cetaceans 10:106.

Bérubé, M., A. Aguilar, D. Dendanto, F. Larsen, G. Notarbartolo di Sciara, R. Sears, J. Sigurjónsson, J. Urban-R. ANd P. J. PAlsbøll. 1998. Population genetic structure of North Atlantic, Mediterranean and Sea of Cortez fin whales, Balaenoptera physalus (Linnaeus 1758): Analysis of mitochondrial and nuclear loci. Molecular Ecology 15:585-599.

BEST, P. B. 1988. Right whales Eubalaena australis at Tristan da Cunha-a clue to the "nonrecovery" of depleted stocks? Biological Conservation 46:23-51.

Best, P. B., A. Brandao AND D. S. Butterworth. 2001. Demographic parameters of southern right whales off South Africa. Journal of Cetacean Research and Management (Special Issue) 2:161-169.

Bossart, J. L., AND D. P. Prowell. 1998. Genetic estimates of population structure and gene flow: Limitations, lessons, and new directions. Trends in Ecology and Evolution 13:202-206.

Branch, T. A., K. M. Stafford, D. M. Palacios, C. Allison, J. L. Bannister, C. L. K. Burton, E. Cabrera, C. A. Carlson, B. Galletti Vernazzani, P. C. Gill, R. Hucke-Gaete, K. C. S. Jenner, M.-N. M. Jenner, K. Matsuoka, Y. A. Mikhalev, T. Miyashita, M. G. Morrice, S. Nishiwaki, V. J. Sturrock, D. Tormosov, R. C. ANDERSON, A. N. BAKer, P. B. Best, P. Borsa, R. L. Brownell JR., S. Childerhouse, K. P. Findlay, T. Gerrodette, A. D. Ilangakoon, M. Joergensen, B. Kahn, D. K. Ljungblad, B. Maughan, R. D. McCauley, S. McKay, T. F. NorRis, OMAN Whale AND DOlPhin ReSEARCH Group AND S. Rankin. 2007. Past and present distribution, densities and movements of blue whales Balaenoptera musculus in the Southern Hemisphere and northern Indian Ocean. Mammal Review 37:116-175.

BRown, S. G. 1976. Modern whaling in Britain and the northeast Atlantic Ocean. Mammal Review 6:25-36.

Brown, S. G. 1986. Twentieth century records of right whales (Eubalaena glacialis) in the northeast Atlantic Ocean. Report of the International Whaling Commission (Special Issue 10):121-127.

Brownell, R. L. JR., P. J. Clapham, T. Kasuya and T. Miyashita. 2001. Conservation status of North Pacific right whales. Journal of Cetacean Research and Management (Special Issue) 2:269-286.

Christensen, I., T. HAUG AND N. ØIEN. 1992. Seasonal distribution, exploitation and present abundance of stocks of large baleen whales (Mysticeti) and sperm whales (Physeter macrocephalus) in Norwegian and adjacent waters. ICES Journal of Marine Science 49:341355.

CLAPHAM, P. J. 1996. The social and reproductive biology of humpback whales: An ecological perspective. Mammal Review 26:27-49.

Clapham, P., AND C. S. BAKer. 2002. Modern whaling. Pages 1328-1332 in W. F. Perrin, B. Würsig and J. G. M. Thewissen, eds. Encyclopedia of marine mammals. Academic Press, San Diego, CA. 
Clapham, P. J., AND J. LinK. 2006. Whales, whaling and ecosystems in the North Atlantic. Pages 241-250 in J. Estes, ed. Whales, whaling and ecosystems. University of California Press, Berkley, CA.

Clapham, P. J., AND C. A. MAYO. 1987. Reproduction and recruitment of individually identified humpback whales, Megaptera novaeangliae, observed in Massachusetts Bay, 1979-1985. Canadian Journal of Zoology 65:2853-2863.

Clapham, P. J., AND I. E. SEIPT. 1991. Resightings of independent fin whales, Balaenoptera physalus, on maternal summer ranges. Journal of Mammalogy 72:788-790.

Clapham, P. J., S. B. YOUNG AND R. L. Brownell, JR. 1999. Baleen whales: Conservation issues and the status of the most endangered populations. Mammal Review 29:35-60.

COLLETT, R. 1909. A few notes on the whale Balaena glacialis and its capture in recent years in the North Atlantic by Norwegian whalers. Proceedings of the Zoological Society, London 7:91-98 + 27 plates.

CumBAA, S. L. 1986. Archaeological evidence of the 16th century Basque right whale fishery in Labrador. Report of the International Whaling Commission (Special Issue 10):187-190.

Dawbin, W. H. 1966. The seasonal migratory cycle of humpback whales. Pages 145-171 in K. S. Norris, ed. Whales, dolphins and porpoises. University of California Press, Berkeley, CA.

DE JONG, C. 1983. The hunt of the Greenland whale. A short history and statistical sources. Report of the International Whaling Commission (Special Issue 5):83-106.

DE KORTE, J., AND S. E. BELIKOV. 1994. Observations of Greenland whales (Balaena mysticetus), Zemlya Frantsa-Iosifa. Polar Record 30:135-136.

Dizon, A. E., C. Lockyer, W. F. Perrin, D. P. Demaster AND J. Sisson. 1992. Rethinking the stock concept: A phylogeographic approach. Conservation Biology 6:24-36.

Donovan, G. P. 1991. A review of IWC stock boundaries. Reports of the International Whaling Commission (Special Issue 13):39-68.

ELL, S. 1995. Sealing and whaling days in New Zealand. Bush Press, Auckland, New Zealand.

GibBS, N., AND S. CHILDERHOUSE. 2000. Humpback whales around New Zealand. Conservation Advisory Science Notes, No. 287. Department of Conservation, Wellington, New Zealand.

Gibis, N., D. Paton, S. Childerhouse And P. Clapham. 2006. Assessment of the current abundance of humpback whales in the Lomaiviti Island group of Fiji and a comparison with historical data. International Whaling Commission Doc. SC/A06/HW34, 21 pp. (Available from IWC, The Red House, 135 Station Road, Impington, Cambridge CB24 9NP, U.K.)

GRAY, R. 1929. The extermination of whales. Nature 123:314-315.

Herman, L. M. 1979. Humpback whales in Hawaiian waters: A study in historical ecology. Pacific Science 33:1-15.

IwC. 1980. Thirtieth report of the International Whaling Commission. Report of the International Whaling Commission 30.

IWC. 2001. Report of the workshop on status and trends in western North Atlantic right whales. Journal of Cetacean Research and Management (Special Issue) 2:61-87.

JACOBSEN, K. O., M. MARX AND N. ØIEN. 2004. Two-way trans-Atlantic migration of a North Atlantic right whale (Eubalaena glacialis). Marine Mammal Science 20:161-166.

JONSGÅRD, A. 1982. Bowhead (Balaena mysticetus) surveys in Arctic northeast Atlantic waters in 1980. Report of the International Whaling Commission 32:355-356.

KASAHARA, A. 1950. Whaling and its resources in the Japanese coastal waters. Bulletin of the Research Institute of the Nikon Suisan Company Limited 4. 103 pp +95 figures [In Japanese].

KasuYA, T. 2002. Japanese whaling. Pages 655-662 in W. F. Perrin, B. Wursig, and J. G. M. Therwissen, eds. Encyclopedia of marine mammals. Academic Press, San Diego, CA.

KATO, H., AND T. KASUYA. 2002. Some analyses on the modern whaling catch history of the western North Pacific stock of gray whales (Eschrichtius robustus). Journal of Cetacean Research and Management 4:277-282. 
KatonA, S. K., And J. A. Beard. 1990. Population size, migrations and feeding aggregations of the humpback whale (Megaptera novaeangliae) in the western North Atlantic Ocean. Report of the International Whaling Commission (Special Issue 12):295305.

Kraus, S. D., J. H. Prescott, A. R. Knowlton and G. S. Stone. 1986. Migration and calving of right whales (Eubalaena glacialis) in the western North Atlantic. Report of the International Whaling Commission (Special Issue 10):139-144.

Kraus, S. D., M. W. Brown, H Caswell, C. W. Clark, M. Fujiwara, P. K. Hamilton, R. D. Kenney, A. R. Knowlton, S. Landry, C. A. Mayo, W. A. Mclellan, M. J. Moore, D. P. NowaceK, D. A. Pabst, A. J. Read and R. M. Rolland. 2005. North Atlantic right whale in crisis. Science 309:561-562.

Larsen, A. H., J. Sigurjónsson, N. Óien, G. Vikingsson and P. J. Palsbøll. 1996. Population genetic analysis of mitochondrial and nuclear genetic loci in skin biopsies collected from central and northeastern North Atlantic humpback whales (Megaptera novaeangliae): Population identity and migratory destinations. Proceedings of the Royal Society of London, Series B, 263:1611-1618.

LINDQUIST, O. 1994. Whales, dolphins and porpoises in the conomy and culture of peasant fishermen in Norway, Orkney, Shetland, Faeroe Islands and Iceland, ca. 900-1900 AD, and Norse Greenland, ca. 1000-1500 AD. Ph.D. thesis, University of St. Andrews, St. Andrews, UK. 343 pp.

Marine Mammal Protection ACT. 1972 (as amended through 1997). US Congress (16 U.S.C. 1361-1407, P.L. 92-522, October 21, 1972, 86 Stat. 1027, http://www.nmfs.noaa.gov/pr/pdfs/laws/mmpa.pdf. (Accessed 6 November 2007)).

Mattila, D. K., P. J. Clapham, O. VÁsQuez and R. Bowman. 1994. Occurrence, population composition and habitat use of humpback whales in Samana Bay, Dominican Republic. Canadian Journal of Zoology 72:1898-1907.

MCQUAID, C. D. 1986. Post-1980 sightings of bowhead whales (Balaena mysticetus) from the Spitsbergen stock. Marine Mammal Science 2:316-318.

Mead, J. G., And E. D. Mitchell. 1984. Atlantic gray whales. Pages 33-53 in M. L. Jones, S. L. Swartz and S. Leatherwood, eds. The gray whale. Academic Press, New York, NY.

MikhaleV, Y. A. 2000. Biological characteristics of humpback whales taken in Antarctic Area V by the whaling fleets Slava and Sovietskaya Ukraina. Paper SC/52/IA12, 18 pp. (Available from IWC, The Red House, 135 Station Road, Impington, Cambridge CB24 9NP, U.K.)

MikHALEV, Y. A. 2004. Trade and the biological characteristic of humpback whales, caught by Soviet Antarctic flotillas into the season 1960-61. Paper SC/56/SH9, 12 pp. (Available from IWC, The Red House, 135 Station Road, Impington, Cambridge CB24 9NP, U.K.)

MiYASHITA, T., H. KATO AND T. KASUYA, eds. 1995. Worldwide map of cetacean distribution based on Japanese sighting data (volume 1). National Research Institute of Far Seas Fisheries, Shimizu, Japan, 140 pp.

Moore, M. J., S. D. Berrow, B. A. Jensen, P. Carr, R. Sears, V. J. Rowntree, R. Payne AND P. K. HAMILTON. 1999. Relative abundance of large whales around South Georgia (1979-1998). Marine Mammal Science 15:1287-1302.

Moore, S. E., AND R. R. ReEves. 1993. Distribution and movement. Pages 313-386 in J. J. Burns, J. J. Montague and C. J. Cowles, eds. The bowhead whale. Special Publication Number 2, Society for Marine Mammalogy, Lawrence, KS.

MORITZ, C., AND D. P. FAITH. 1998. Comparative phylogeography and the identification of genetically divergent areas for conservation. Molecular Ecology 7:419-429.

National OCEANiC AND Atmospheric Administration. 2005. New priorities for the 21st century-NOAA's Strategic Plan, Updated for FY 2006-FY 2011. NOAA, US Department of Commerce, http://www.nssl.noaa.gov/aboutnss/strategic_plan_2006_ final_04282005.pdf. (Accessed 6 November 2007). 
Notarbartolo Di Sciara, G., E. Politi, A. Bayed, P. Beaubrun and A. Knowlton. 1997. A winter cetacean survey off southern Morocco, with a special emphasis on suitable habitats for wintering right whales. International Whaling Commission Doc SC/49/03, 16 pp. (Available from IWC, The Red House, 135 Station Road, Impington, Cambridge CB24 9NP, U.K.)

OHSUMI, S., AND Y. MASAKI. 1975. Japanese whale marking in the North Pacific, 1963-1972. Bulletin of the Far Sea Fisheries Research Laboratory 12:171-219.

Olavarría, C., C. S. Baker, C. Garrigue, M. Poole, N. Hauser, S. Caballero, L. Flórez-gonzález, M. Brassuer, J. Capella, P. Clapham, R. Dodemont, M. Donoghue, M.n. Jenner, D. Moro, M. Oremus, D. Paton and K. Russell. 2007. Population structure of humpback whales throughout the South Pacific, and the origin of the eastern Polynesian breeding grounds. Marine Ecology Progress Series 330:257-268.

PAETKAU, D. 1999. Using genetics to identify intraspecific conservation units: A critique of current methods. Conservation Biology 13:1507-1509.

Palsbøll, P. J., P. J. Clapham, D. K. Mattila, F. Larsen, R. Sears, H. R. Siegismund, J. SigurJónSSON, O. VÁsQUEZ AND P. ARCTANDER. 1995. Distribution of mtDNA haplotypes in North Atlantic humpback whales: The influence of behavior on population structure. Marine Ecology Progress Series 116:1-10.

Raga, J. A., AND J. PANTOJA, eds. 2004. Proyecto Mediterráneo. Zonas de especial interés para la conservación de los cetáceos en el Mediterráneo español, 219 pp. Ministerio de Medio Ambiente. Organismo Autónomo Parques Nacionales, Madrid, Spain.

Rastogi, T., M. W. Brown, B. A. McLeod, T. A. Frasier, R. Grenier, S. L. CumbaA, J. NADARAJAH AND B. N. White. 2004. Genetic analysis of 16th-century whale bones prompts a revision of the impact of Basque whaling on right and bowhead whales in the western North Atlantic. Canadian Journal of Zoology 82:1647-1654.

ReEves, R. R. 1980. Spitsbergen bowhead stock: A short review. Marine Fisheries Review 42:65-69.

ReEves, R. R., AND E. MitChelL. 1986. American pelagic whaling for right whales in the North Atlantic. Report of the International Whaling Commission (Special Issue 10):221-254.

Reeves, R. R., P. J. Clapham, R. L. Brownell, JR. AND G. K. Silber. 1998. Recovery plan for the blue whale (Balaenoptera musculus). Office of Protected Resources, NMFS, NOAA, Silver Spring, MD, 30 pp.

Reeves, R. R., S. Swartz, S. E. Wetmore and P. J. Clapham. 2001. Historical occurrence and distribution of humpback whales in the eastern and southern Caribbean Sea, based on data from American whaling logbooks. Journal of Cetacean Research and Management 3:117-129.

ReILLY, S. B. 1992. Population biology and status of eastern Pacific gray whales: Recent developments. Pages 1062-1074 in D. R. McCullough and R. H. Barrett, eds. Wildlife 2001: Populations. Elsevier Applied Science, New York, NY.

SANPERA, C., AND A. Aguilar. 1992. Modern whaling off the Iberian peninsula during the 20th century. Report of the International Whaling Commission 42:723-730.

Shelden, K. E. W., AND D. J. Rugh. 1995. The bowhead whale, Balaena mysticetus: Its historic and current status. Marine Fisheries Review 57:1-20.

SMITH, T. D., K. BARTHELMESS AND R. R. REEVES. 2006. Using historical records to relocate a long-forgotten summer feeding ground of North Atlantic right whales. Marine Mammal Science 22:723-734.

STEVick, P. T., C. A. CARlso AND K. C. BALCOMB. 1999. A note on the migratory destinations of humpback whales from the eastern Caribbean. Journal of Cetacean Research and Management 1:251-254.

Swartz, S. L., T. Cole, M. A. Mcdonald, J. A. Hildebrand, E. M. Oleson, A. Martinez, P. J. Clapham, J. BARlow AND M. L. JONES. 2003. Acoustic and visual survey of humpback whale (Megaptera novaeangliae) distribution in the eastern and southeastern Caribbean Sea. Caribbean Journal of Marine Science 39:195-208. 
TAYLOR, B. L. 1997. Defining “population” to meet management objectives for marine mammals. Pages 49-65 in A. E. Dizon, S. J. Chivers and W. F. Perrin, eds. Molecular genetics of marine mammals. Special Publication Number 3, Society for Marine Mammalogy, Lawrence, KS.

TAYLOR, B. L. 2005. Identifying units to conserve. Pages 149-164 in J. E. Reynolds III, W. F. Perrin, R. R. Reeves, S. Montgomery and T. J. Ragen, eds. Marine mammal research: Conservation beyond crisis. The John Hopkins University Press, Baltimore, MD.

TAYLOR, B. L., AND A. E. DizON. 1999. First policy then science: Why a management unit based solely on genetic criteria cannot work. Molecular Ecology 8:S11-S16.

TAYLOR, B. L., S. J. Chivers AND A. E. DizON. 1997. Using statistical power to interpret genetic data to define management units for marine mammals. Pages 347-364 in A. E. Dizon, S. J. Chivers and W. F. Perrin, eds. Molecular genetics of marine mammals. Special Publication Number 3, Society for Marine Mammalogy, Lawrence, KS.

TøNNESSEN, J. N., AND A. O. JOHNSEN. 1982. The history of modern whaling. C. Hurst and Company, London, U.K.

TYACK, P. 1981. Interactions between singing Hawaiian humpback whales and conspecifics nearby. Behavioral Ecology and Sociobiology 8:105-116.

WADE, P. R., AND R. ANGLISS. 1997. Guidelines for assessing marine mammal stocks: Report of the GAMMS workshop April 3-5, 1996, Seattle, WA. U.S. Department of Commerce, NOAA Technical Memorandum NMFS-OPR-12, 93 pp.

WAPLES, R. S., AND O. GAGGIOTTI. 2006. What is a population? An empirical evaluation of some genetic methods for identifying the number of gene pools and their degree of connectivity. Molecular Ecology 15:1419-1439.

Weller, D. W., A. M. Burdin, B. WÜersig, B. L. TAYlor ANd R. L. Brownell, JR. 2002. The western gray whale: A review of past exploitation, current status and potential threats. Journal of Cetacean Research and Management 4:7-12.

WIIG, Ø. 1991. Seven bowhead whales (Balaena mysticetus L.) Observed at Franz Josef in 1990. Marine Mammal Science 7:316-319.

WiIG, Ø., L. BACHMANN, V. M. JANIK, K. M. KovaCS AND C. LYDERSEN. 2007. Spitsbergen bowhead whales revisited. Marine Mammal Science 23:688-693.

WinN, H. E., R. K. EDEL AND A. G. TARUSKI. 1975. Population estimate of the humpback whale (Megaptera novaeangliae) in the West Indies by visual and acoustic techniques. Journal of the Fisheries Research Board of Canada 32:499-506.

Yablokov, A. V., V. A. Zemsky, Y. A. Mikhalev, V. V. Tormosov and A. A. Berzin. 1998. Data on Soviet whaling in the Antarctic in 1947-1972 (population aspects). Russian Journal of Ecology 29:38-42.

Zannèse, A., N. Morellet, C. Targhetta, A. Coulon, S. Fuser, A. J. M. Hewison AND M. RAMANZIN. 2006. Spatial structure of roe deer populations: Towards defining management units at a landscape scale. Journal of Applied Ecology 43:1087-1097.

Zeh, J. E., C. W. Clark, J. C. George, D. Withrow, G. M. Carroll and W. R. Koski. 1993. Current population size and dynamics. Pages 409-489 in J. J. Burns, J. J. Montague and C. J. Cowles, eds. The bowhead whale. Special Publication Number 2, Society for Marine Mammalogy, Lawrence, KS.

Zemsky, V. A., A. A. Berzin, Y. A. Mikhaliev and D. D. Tormosov. 1995. Soviet Antarctic pelagic whaling after WWII: Review of actual catch data. Report of the International Whaling Commission 46:131-135.

Received: 6 December 2006 Accepted: 26 September 2007 